IJMPB

1,1

Received 10 October 2007 Accepted 24 October 2007

\section{RESEARCH NOTE \\ The other side of projects: the case for critical project studies}

\author{
Damian Hodgson
}

Manchester Business School, University of Manchester, Manchester, UK, and

Svetlana Cicmil

Bristol Business School, University of the West of England, Bristol, UK

\begin{abstract}
Purpose - The purpose of this research note is to articulate the limitations that project management (PM) currently faces by outlining the PM literature's frequent neglect of political, social and ethical dimensions of PM work in order to raise a number of important themes that can be usefully integrated into mainstream PM literature.

Design/methodology/approach - Extensive research note which updates us on where PM research is heading.

Findings - PM is a highly complex, political and social process. The paper challenges readers, PM academics and practitioners to view PM more critically and to expand their appreciation of PM work as being more complex in its social context that merely delivering instrumentalist and mechanistic functional management processes.

Originality/value - This paper triggers a debate using critical PM research to engage with all levels of the project hierarchy with the aim of initiating some transformation in how actors perceive themselves, their voice, their broad responsibility and their influence in shaping their own social place.
\end{abstract}

Keywords Project management, Project evaluation

Paper type Research paper

\section{Introduction}

The achievements of project management (PM) and project managers have been broadly extolled by those within the field for many years, and the sentiment that these achievements were not sufficiently recognised or understood in wider society has long persisted. There are signs in recent years that this inattention is at last being reversed, and that both looking back and looking forward, there is evidence that corporations, sponsors, governments, international bodies and indeed fellow employees and managers are now paying serious attention to what PM as a discipline has achieved, and what it can contribute in the future.

This "coming of age" of the discipline is welcome, and represents a huge opportunity for the field of PM to establish itself across public and private sectors, and to make a greater contribution to organisations, economies and societies. It is precisely at this moment, facing this opportunity, that we wish to raise a cautionary note. To take its place as a mature and self-confident discipline, as has been noted by several authors, PM requires a broadening and deepening of the theoretical base of PM, as befits a mature and confident discipline (Winch, 1996; Morris et al., 2000; Maylor, 2001; Koskela and Howell, 2002; Morris, 2004). Clearly, PM has developed continually since
International Journal of Managing Projects in Business

Vol. 1 No. 1,2008

pp. $142-152$

(c) Emerald Group Publishing Limite $1753-8378$

DOI 10.1108/17538370810846487 
the early work on scheduling in the first half of the twentieth century, and important contributions and advances have been made year upon year. What we are arguing for in this research note is specifically a broadening of the agenda, and more importantly a recognition of the social and ethical territory that PM already occupies, but frequently fails to reflect upon (Cicmil, 2006; Hodgson and Cicmil, 2006; Cicmil and Hodgson, 2006). We might refer to this occluded face of PM as "the other side" of the discipline, in terms of what is overlooked but also in terms of what is often actively ignored and obscured, including the sometimes dysfunctional consequences of PM practice - for the individual, for the environment and for society as a whole. This we argue would involve identifying and encouraging research which explores new perspectives and new themes which lie outside the tightly defined and densely populated conceptual landscape of mainstream PM.

Our argument in this research note will centre on three main themes. First of all, we must articulate the limitations that PM currently faces, many of which are widely recognised within the field, and the ongoing efforts to "rethink" the basis of the discipline to overcome these limitations. We then will outline one important dimension which is by and large neglected by the majority of work on PM; the political, social and ethical dimension to PM in both theory and practice. Drawing on the tradition referred to as "Critical management studies" we will outline what a "Critical project studies" might embrace and aim to achieve. Finally, drawing on an incipient critical literature, both within and outside the PM field, we would like to raise a number of important themes and make a case for a greater recognition and integration of these concerns into mainstream PM.

\section{Challenging project management}

In recent years, PM has attracted increasing attention from researchers, organisations, and local and national governments, which in one sense reflects the increased adoption of project-based work across industrial sectors[1]. Both practitioner and academic discourses have hailed the project form as a vital economic and social process on which the emerging "knowledge economy" heavily relies (Frame, 1994; Briner and Hastings, 1994; Cleland and Ireland, 2002; Meredith and Mantel, 2003). Three key characteristics of modern organisations and society are typically cited in the rise of the project form; rapidly changing environments and markets, the increasing complexity of products and services and the corresponding knowledge intensity in production processes. Not only are projects considered suitable ways to control endeavours in a turbulent environment (Ekstedt et al., 1999), but more importantly, they are also regarded as the appropriate way to stimulate a learning environment and enhance creativity so as to deliver complex products (Hobday, 2000). Recent literature has highlighted the importance of project-based organizing in the processes of information sharing and knowledge management in organizations (Silver, 2000; de Fillippi, 2001). In this context, PM has been promoted as a powerful and widely-applicable vehicle for integrating diverse functions of an organization, enabling the efficient, timely, and effective accomplishment of goals through the concentration of flexible, autonomous, and knowledgeable individuals in temporary teams. PM and projects have seemingly been accepted by many both within and outside the field as natural, self-evident, and indispensable.

\section{Critical project studies}

143 
IJMPB 1,1

\section{4}

It is at this point, however, that the paradox of PM as powerful and generalisable solution to the acknowledged challenges of the new economic and social era becomes apparent. A growing body of literature, as well as a growing body of empirical evidence and the voices of numerous practitioners indicate that accepting and applying this widely promoted PM "good practice" standards does not eliminate project failures, nor does it guarantee project success (Williams, 2004). On the contrary, a number of empirical studies suggest that the very reason for using projects and PM as a methodology for organisational innovation and change is at the heart of project failures (Currie, 1994; Thomas, 2000; Maylor, 2001). Thus, Clarke (1999) questions the value of $\mathrm{PM}$ as a vehicle of change, arguing instead that standardised PM often is itself the cause of project overload, cultural clashes, and engenders individual resistance to imposed procedures and practice. In such (not untypical) circumstances, the selfsame principles of structured PM methodology are simultaneously the major causes of failure.

Equally worryingly, contemporary studies of project performance continue to indicate the disparity between the maturing body of PM know-how and the effectiveness of its application (Williams, 1999; Atkinson, 1999; Morris et al., 2000). Recent public reports provide an insight into frequent cost overruns, delays, and under-performance in terms of quality and user satisfaction, which seem to have become the rule and the reality of contemporary projects (Morris and Hough, 1987; Flyvbjerg et al., 2002, 2003). The litany of high-profile project debacles has provided a recurrent theme over the last two decades, encompassing Denver Airport, the Jubilee Line extension to the London Underground, the Scottish Parliament and already many predict a similar story for the 2012 London Olympics. Evidence of poor project performance can be found across various industries and types of project (Standish Group, 1994; Bowen et al., 1994; Winch, 1996).

Project failure rates tend to be fiercely contested, and we would also be sceptical of easy attributions of "success" and "failure"; as Fincham (2002, p. 1) suggests, these accounts can seen as narratives whereby "through a kind of social labelling events are formulated into evolving 'stories' that evoke either status or stigma”. More widely, however, the wider consequences of project failures tend to go unnoticed, and often suppressed. This is the issue of general neglect of the social complexity in project environments in conceptualising key performance indicators against which projects are evaluated and approved. As numerous reports in the public domain about the implications and consequences for multiple communities affected by important major projects indicate (e.g. the Three Gorges Dam, Shell's Sakhalin 2 oil and gas project, the 2012 Olympics), economic measures tend to dominate decision-making processes and to marginalise values, interests and risks related to health, safety, well-being, the environment and long-term possibilities for collaboration and sustainable development.

Ironically, however, part of the current high profile of PM stems from the widely publicised instances of PM failure, particularly in public sector-related projects and in IS/IT. A long-standing international debate about the formulation of the various bodies of knowledge, regarding the boundaries of the subject area, its purpose, practical application, and relationship with other aspects of organisational and managerial reality (Wideman, 1995; Morris et al., 2000; Koskela and Howell, 2002; Meredith and Mantel, 2003, among others) has been driven by the aim of radically examining the intellectual foundation of PM, thus tackling the perceived root of the problems. 
In general, there remains a tendency in the field to assume that the basic framework of PM is compelling and essentially sound, and to see failings in PM as normal in a maturing field, and soon to be ironed out through more complex and elaborate modelling of project planning and monitoring problems and solutions, including an increased reliance on IS/IT and software-based tools (Maylor, 2003; Meredith and Mantel, 2003). Despite the increased sophistication of these models and proliferation of PM text-books, consultancy support and governmental policies, it is still unclear to what extent these complex tools are being actually used by practitioners.

Other attempts to move the field forward (Soderlund, 2005) include research on projects as vehicles for individual and organisational learning (Prencipe and Tell, 2001; Newell et al., 2006), research which adopts a knowledge management perspective (Kasvi et al., 2003; Bresnen et al., 2004) and work informed by familiar aspects of occupational psychology such as leadership and personality (Shenhar, 2004). Another approach which broadens the agenda in a productive manner is the more political analysis of projects as organisational and social arrangements which gained some prominence from the 1990s onwards. An precursor of this approach is Taggert and Silbey's (1986) world-weary "political" development cycle of projects, which replaces the four stages of the traditional, linear project life cycle (PLC) (conception, planning, execution/control and closure) with an alternative life-cycle whose stages include wild enthusiasm; disillusionment; total confusion; search for the guilty; punishment of the innocent and promotion of non-participants. Political perspectives on projects tends to suggest the need for a wider picture which considers what goes on in social construction of projects and PM by focusing on who and which agendas are included in or excluded from decision-making processes (Flyvbjerg et al., 2003; Marshall and Rollinson, 2004). Particularly influential here is the Scandinavian School of Project Studies (Sahlin-Anderson and Söderholm, 2002) which moves beyond traditional understandings of projects and their management, positing among other things the conceptualisation of projects as temporary organisations (Lundin and Söderholm, 1995) and the recognition of the historically embedded nature of projects (Kreiner, 1995; Engwall, 2003).

\section{Towards a constructive critique}

While recognising the advances made in these various directions, we would suggest that the problem is far more deeply rooted in the fundamental principles upon which the field of PM has been established. More widely, however, we need to address the wider consequences of the contemporary PM discourse which tend to go unnoticed, and often suppressed.

Our concern is that research into projects and PM remains heavily reliant on a functionalist, instrumental view of projects and organisations, where the function of PM is taken to be the accomplishment of some finite piece of work in a specified period of time, within a certain budget, and to agreed specifications. Most textbooks and professional associations for PM enthusiastically promote this normative view of the field, involving the application of knowledge, skills, tools and techniques to project activities to meet project requirements. This position typically assumes rationality, universality, objectivity, and value-free decision making, and the possibility of generating law-like predictions in knowledge. Carrying the legacy of the tradition of "natural sciences" (e.g. systems theory), much of PM theory and commonplace prescription continues to emphasise the role of project managers as "implementers"

\section{Critical project studies}

145 


\section{IJMPB 1,1}

whose role and responsibility is merely to address issues of control (time and cost) and content (planned scope of work). This position explicitly and deliberately marginalises and suppresses their wider potential role as competent social and political actors in complex project-labelled arrangements. Efforts to dissemination and institutionalise "best practice" across and between industries and sectors reflects and pursues the progressive rationalisation of action in project contexts. The consequences of this situation are both ethical and deeply practical - as Balck (1994, p. 2) argues:

Practitioners, in particular we as project managers, are well advised to rid ourselves of the constricting historical background of a mechanistic world image and rationalism.

Our proposal is to draw on the insights offered by the broad grouping of critical management studies to widen and deepen the theoretical foundations of PM and to provide novel approaches to the entrenched challenges facing PM. Critical work on management and organisations has an eclectic base, and draws upon a wide range of social theories, philosophies and ethical/moral positions, including Marxism, feminism, environmentalism, labour process theory, post-structuralism, post-colonialism and critical realism (for a summary, see Alvesson and Willmott, 1996; Grey and Willmott, 2005). Given this diversity, Fournier and Grey (2000) set out three key tenets which critical work largely shares. They argue that critical research on management and organisations:

- Has a "Non-performative intent" - starts out from the position that issues of morality, equality and ethics are as important as - or more important than traditional functionalist concerns of organisational effectiveness and efficiency.

- "Aims to denaturalise organisations and management" - challenges work which asserts that the current way in which organisations, economies and societies are organised is somehow natural, normal or inevitable, drawing attention instead to political and power relations underpinning any "status quo".

- "Aims to prevent oppression/exploitation" - the overarching concern for such work is to oppose oppression and exploitation in organisations and societies, whether this be the exploitation of employees, of women, of ethnic minorities, or of the environment.

Much of this work has since the mid-1990s been collectively referred to as "Critical management studies" and "CMS" has also lent its name to a major international conference as well as to a major Interest Group at the Academy of Management. Such work takes specific issue with moves to reduce management to value-neutral competence, and rejects what is core to PM's instrumentalist ethos; "the means-end calculus with economic efficiency as guiding theme, ethics and values ignored, truncated or subsumed within efficiency" (Grey, 2005, p. 8). CMS-inspired work therefore resists the suppression of the political, ethical and moral aspect of organisations and management, arguing that this is far removed from the reality of management which is "often messy, ambiguous, fragmented and political in character" (Alvesson and Deetz, 2000, p. 60).

Over the last decade, work has emerged which applies this critical position to PM, its nostrums and methods - this work, although drawn from many disciplinary backgrounds and theoretical positions, share a focus on critical issues and might be seen as the emergence of a school of critical project studies. Some of this work is 
brought together in an edited collection by the authors (Hodgson and Cicmil, 2006); others can be found across the range of management, business and engineering journals. In the following section, we will attempt to give a brief overview of the existing literature which pursues critical themes and develops insights based on empirical work in a variety of project organisations and sectors.

One key critical research theme (Hodgson, 2002; Thomas, 2006) is a focus on the consequences of those techniques of observation, measurement and performance control central to PM methodologies for both the management and the self-management of workers within project settings. Work on PM in this tradition tends to criticise PM methodology, as, first and foremost, the attempt to impose control upon employees (Metcalfe, 1997), using similar principles of work fragmentation and the maximisation of visibility and accountability to those underpinning scientific management (Whitty and Schulz, 2007). Some of this work points to the self-defeating nature of the control imperative central to PM (Drummond and Hodgson, 2003); other work points to the deleterious effects of control and work intensification on learning and knowledge transfer in such environments (Koch, 2004; Lindgren and Packendorff, 2006b). A strong current of research in this vein focuses upon the intensified nature of work in project environments (Garrick and Clegg, 2001; Zika-Victorsson et al., 2006) and the impact of precarious working in many project industries (Eskinsmyth, 2002; Green, 2006). This insight is extended beyond the workplace in research on the impact of projects working on work-life balance (Lindgren and Packendorff, 2006a), drawing attention to the discriminatory aspect while other work takes a slightly different approach, analysing instead the gendered nature of PM models and procedures (Buckle and Thomas, 2003; Thomas and Buckle-Henning, 2007).

At the same time, the ongoing professionalisation of PM has been interpreted in line with other professionalisation projects, as a mode of control over expert labour, implementing and enforcing a form of self-disciplinary control over project managers (Hodgson, 2002). A key challenge for critical work from this perspective is thus to draw attention to the subtle power relations established and maintained by PM technologies through the monopoly of language and discourse (Raisanen and Linde, 2004; Hodgson and Cicmil, 2007) and the consequences of these power relations for practice in project settings. A parallel but equally vital line of examination looks at the role of PM in perpetuating oligarchic elites in modern corporations (Clegg and Courpasson, 2004), and analyses of PM as a form of bureaucratic control, imposing administrative constraints at the expense of creativity and autonomy (Hodgson, 2004; Styhre, 2006).

\section{Towards critical project studies}

Our immediate objective is to signpost possible research trajectories towards a critical evaluation of the intellectual foundations of PM as a field of study and a practising discipline and to broaden the research agenda by encouraging a more critical approach in this increasingly prominent area of organisational life. In doing so, we are taking up the challenge offered by Flyvbjerg (2001, p. 166) to conduct research that "contributes to society's capacity for value-rational deliberation and action". Our hope is that this paper may encourage movement towards the creation of a vocabulary and a resource for a critical engagement between practitioners and academics beyond the confines of the existing language, concepts and assumptions of PM.

\section{Critical project studies}

147 
IJMPB 1,1

\section{8}

The first and most important consequence of an engagement with critical work would be an increased sensitivity to the possibility of oppression and exploitation in project settings, an outcome which is especially likely given the pressurised environment of most projects, regardless of sector and scale. A second important aspect of critical approaches to PM is to rethink definitions of project success beyond time, cost and quality performance to encompass work-life balance, societal impacts, health and safety, and ethical concerns more widely. And, thirdly, critical PM research would engage with (and serve) not merely project managers but practitioners at all levels of the project hierarchy, often with the aim of initiating some transformation in how actors perceive themselves, their voice, their broad responsibility and their influence in shaping their own social place.

Our intention in presenting these views is primarily to start a dialogue, to raise the importance of such issues and concerns within the field of PM and to draw attention to broader theoretical resources available to conceptualise projects and their management. To this end, we have in the past organised workshops to act as a forum for debates around these themes, of which the best papers have been published as a collection (Hodgson and Cicmil, 2006). We continue to run these workshops, in the hope of extending the debate and learning from the views, experiences and insights of as broad a range as possible, and we would welcome interventions, participation and even counter-critique from all quarters. We hope that, at the least, this research note has succeeded in raising new concerns and has sharpened interest among PM academics and practitioners to engage with these concerns, which are central to the future of an ethical, politically self-aware and in the broadest sense "effective" PM.

In the process of establishing a field, it is entirely understandable that the focus is upon extolling the virtues, values and achievements of PM in the face of indifference, rivalry and scepticism, and suppressing or ignoring both the failings of PM and also the negative consequences of PM at its most successful. One of the prices of maturity is the requirement to critique oneself in a far more rigorous and extensive manner. This undertaking is already underway, and we would hope that this journal would be an important forum for the debates in this area. We recognise that this requires a fundamental reappraisal of many core tenets of PM theory and technique, an undertaking which poses a challenge for many whose careers and indeed livelihoods are intimately connected to PM as it stands. Nonetheless, without such a radical reappraisal, PM as a discipline will not overcome the practical and philosophical challenges which it currently faces, and will struggle to cope with and influence the broadening field of project organising in the next century.

\section{Note}

1. A process described by some as "projectification" (Midler, 1995; Lundin and Söderholm, 1998; Jessen, 2002; Sydow and Staber, 2002), implying in the extreme the colonisation of all aspects of life by project-related principles, rules, techniques, and procedures.

\section{References}

Alvesson, M. and Deetz, S. (2000), Doing Critical Management Research, Sage, London.

Alvesson, M. and Willmott, H. (1996), Making Sense of Management: A Critical Introduction, Sage, London. 
Atkinson, R. (1999), "Project management: cost, time and quality, two best guesses and a phenomenon; It's time to accept other success criteria”, International Journal of Project Management, Vol. 17 No. 6, pp. 337-42.

Balck, H. (1994), "Projects as elements of a new industrial pattern: a division of project management", in Cleland, D.I. and Gareis, R. (Eds), Global Project Management Handbook, McGraw-Hill, New York, NY, pp. 2-1-2-11.

Bowen, H.K., Clark, K.B., Holloway, C.A. and Wheelwright, S.C. (1994), The Perpetual Enterprise Machine, Oxford University Press, Oxford.

Bresnen, M., Goussevskaia, A. and Swan, J. (2004), "Embedding new management knowledge in project-based organizations", Organization Studies, Vol. 25 No. 9, pp. 1535-55.

Briner, W. and Hastings, C. (1994), "The role of projects in the strategy process", in Cleland, D.I. and Gareis, R. (Eds), Global Project Management Handbook, McGraw-Hill, New York, NY, pp. 15_3-15_24.

Buckle, P. and Thomas, J. (2003), "Deconstructing project management: a gender analysis of project management guidelines", International Journal of Project Management, Vol. 21 No. 6, pp. 433-41.

Cicmil, S. (2006), "Understanding project management practice through interpretative and critical research perspectives", Project Management Journal, Vol. 37, pp. 27-37.

Cicmil, S. and Hodgson, D. (2006), "New possibilities for project management theory: a critical engagement”, Project Management Journal, Vol. 37 No. 3, pp. 111-22.

Clarke, A. (1999), "A practical use of key success factors to improve the effectiveness of project management", International Journal of Project Management, Vol. 17 No. 3, pp. 139-45.

Clegg, S.C. and Courpasson, D. (2004), "Political hybrids: Toquevillean views on project organizations”, Journal of Management Studies, Vol. 41 No. 4, pp. 525-47.

Cleland, D.I. and Ireland, L.R. (2002), Project Management: Strategic Design and Implementation, 4th ed., McGraw-Hill, New York, NY.

Currie, W. (1994), "The strategic management of a large scale IT project in the financial services sector”, New Technology, Work and Employment, Vol. 9 No. 1, pp. 19-29.

DeFillippi, R. (2001), "Project based learning, reflective practices and learning outcomes", Management Learning, Vol. 32, pp. 5-10.

Drummond, H. and Hodgson, J. (2003), “The chimpanzees' tea party: a new metaphor for project managers", Journal of Information Technology, Vol. 18 No. 3, pp. 151-8.

Ekstedt, E., Lundin, R.A., Söderholm, A. and Wirdenius, H. (1999), Neo-industrial Organising, Routledge, London.

Engwall, M. (2003), "No project is an island: linking projects to history and context", Research Policy, Vol. 32 No. 5, pp. 789-808.

Eskinsmyth, C. (2002), "Project organization, embeddedness and risk in magazine publishing", Regional Studies, Vol. 36 No. 3, p. 229.

Fincham, R. (2002), "Narratives of success and failure in systems development", British Journal of Management, Vol. 13 No. 1, pp. 1-14.

Flyvbjerg, B. (2001), Making Social Science Matter, Cambridge University Press, Cambridge.

Flyvbjerg, B., Bruzelius, N. and Rothengatter, W. (2003), Megaprojects and Risk: An Anatomy of Ambition, Cambridge University Press, Cambridge.

Flyvbjerg, B., Holm, M.S. and Buhl, S. (2002), "Underestimating costs in public works projects error or lie?", Journal of American Planning Association, Vol. 68, pp. 279-95.

\section{Critical project studies}




\section{IJMPB 1,1}

Fournier, V. and Grey, C. (2000), "At the critical moment: conditions and prospects for critical management studies”, Human Relations, Vol. 53 No. 1, pp. 7-32.

Frame, J.D. (1994), The New Project Management, Jossey-Bass, San Francisco, CA.

Garrick, J. and Clegg, S. (2001), "Stressed-out knowledge workers in performative times: a postmodern take on project-based learning", Management Learning, Vol. 32 No. 1, pp. 119-34.

Green, S. (2006), "The management of projects in the construction industry: context, discourse and self-identity", in Hodgson, D.E. and Cicmil, S. (Eds), Making Projects Critical, Palgrave, London.

Grey, C. (2005), "Critical management studies: towards a more mature politics", in Howcroft, D. and Trauth, E.M. (Eds), Handbook of Critical Information Systems Research, Edward Elgar, Cheltenham, pp. 174-94.

Grey, C. and Willmott, H. (Eds) (2005), Critical Management Studies: A Reader, Oxford University Press, Oxford.

Hobday, M. (2000), "The project-based organisation: an ideal form for managing complex products and systems?", Research Policy, Vol. 27, pp. 871-93.

Hodgson, D.E. (2002), “Disciplining the professional': the case of project management”, Journal of Management Studies, Vol. 39 No. 6, pp. 803-21.

Hodgson, D.E. (2004), "Project work: the legacy of bureaucratic control in the post-bureaucratic organisation”, Organization, Vol. 11 No. 1, pp. 81-100.

Hodgson, D.E. and Cicmil, S. (2006), Making Projects Critical, Palgrave, London.

Hodgson, D. and Cicmil, S. (2007), "The politics of standards in modern management: making 'the project' a reality”, Journal of Management Studies, Vol. 44 No. 3, pp. 431-50.

Jessen, S.A. (2002), Business by Projects, Universitetsforlaget AS, Oslo.

Kasvi, J.J., Vartiainen, M. and Hailikari, M. (2003), "Managing knowledge and knowledge competences in projects and project organizations", International Journal of Project Management, Vol. 21, pp. 571-82.

Koch, C. (2004), "The tyranny of projects: teamworking, knowledge production and management in consulting engineering", Economic and Industrial Democracy, Vol. 25 No. 2, pp. 277-300.

Koskela, L. and Howell, G. (2002), "The underlying theory of project management is obsolete", Proceedings of PMI Research Conference 2002, Newtown Square, PA: Project Management Institute, pp. 293-301.

Kreiner, K. (1995), "In search of relevance: project management in drifting environments", Scandinavian Journal of Management, Vol. 11 No. 4, pp. 335-46.

Lindgren, M. and Packendorff, J. (2006a), "What's new in new organisational forms? On the construction of gender in project-based work", Journal of Management Studies, Vol. 43 No. 4, pp. 841-66.

Lindgren, M. and Packendorff, J. (2006b), "Projects and prisons", in Hodgson, D. and Cicmil, S. (Eds), Making Projects Critical, Palgrave, Basingstoke.

Lundin, R.A. and Söderholm, A. (1995), “A theory of the temporary organization”, Scandinavian Journal of Management, Vol. 11 No. 4, pp. 437-55.

Lundin, R.A. and Söderholm, A. (1998), "Managing the black boxes of the project environment", in Pinto, J.K. (Ed.), Project Management Handbook, Jossey-Bass, San Francisco, CA, pp. 41-54.

Marshall, N. and Rollinson, J. (2004), "Maybe Bacon had a point: the politics of interpretation in collective sensemaking”, British Journal of Management, Vol. 15, pp. S71-S86. 
Maylor, H. (2001), "Beyond the Gantt chart - project management moving on", European Management Journal, Vol. 19 No. 1, pp. 92-100.

Maylor, H. (2003), Project Management, FT Prentice-Hall, London.

Meredith, J.R. and Mantel, S.L. (2003), Project Management - A Managerial Approach, 5th ed., Wiley, New York, NY.

Metcalfe, B. (1997), "Project management system design: a social and organisational analysis", International Journal of Production Economics, Vol. 52 No. 3, pp. 305-16.

Midler, C. (1995), “Projectification' of the firm: the Renault case”, Scandinavian Journal of Management, Vol. 11 No. 4, pp. 363-73.

Morris, P.W.G. (2004), "Current trends in project and programme management", Association for Project Management Yearbook, Association for Project Management (APM), High Wycombe.

Morris, P.W.G. and Hough, G.H. (1987), The Anatomy of Major Projects, Major Projects Association, London.

Morris, P.W.G., Patel, M.B. and Wearne, S.H. (2000), "Research into revising the APM project management body of knowledge", International Journal of Project Management, Vol. 18 No. 3, pp. 155-64.

Newell, S., Bresnen, M., Edelman, L., Scarbrough, H. and Swan, J. (2006), "Sharing knowledge across projects: limits to ICT-led project review practices", Management Learning, Vol. 37 No. 2, pp. 167-85.

Prencipe, A. and Tell, F. (2001), "Inter-project learning: processes and outcomes of knowledge codification in project-based firms", Research Policy, Vol. 30 No. 9, pp. 373-94.

Raisanen, C. and Linde, A. (2004), "Technologizing discourse to standardize projects in multi-project organizations: hegemony by consensus?", Organization, Vol. 11 No. 1, pp. 101-21.

Sahlin-Andersson, K. and Söderholm, A. (Eds) (2002), Beyond Project Management: New Perspectives on the Temporary-Permanent Dilemma, Liber, Copenhagen.

Shenhar, A.J. (2004), "Strategic project leadership ${ }^{\circledR}$ : toward a strategic approach to project management", R\&D Management, Vol. 34 No. 5, pp. 569-78.

Silver, C.A. (2000), "Where technology and knowledge meet", Journal of Business Strategy, Vol. 21, pp. 28-33.

Soderlund, J. (2005), "What project management really is about: alternative perspectives on the role and practice of project management", International Journal of Technology Management, Vol. 32 Nos 3/4, pp. 371-87.

Standish Group (1994) The Chaos Report, available at: www.standishgroup.com/ (accessed September 16, 2007).

Styhre, A. (2006), "The bureaucratization of the project manager function: the case of the construction industry", International Journal of Project Management, Vol. 24 No. 3, pp. 271-6.

Sydow, J. and Staber, U. (2002), "The institutional embeddedness of project networks: the case of content production in German television”, Regional Studies, Vol. 36, pp. 215-27.

Taggert, W.M. and Silbey, V. (1986), Informational Systems: People and Computers in Organisations, Allyn and Bacon, Boston, MA.

Thomas, J. (2000), "Making sense of project management", in Lundin, R.A. and Hartman, F. (Eds), Projects as Business Constituents and Guiding Motives, Kluwer Academic Press, Boston, MA. 
IJMPB

1,1
Thomas, J. (2006), "Problematizing project management", in Hodgson, D. and Cicmil, S. (Eds), Making Projects Critical, Palgrave, Basingstoke.

Thomas, J.L. and Buckle-Henning, P. (2007), "Dancing in the white spaces: exploring gendered assumptions in successful project managers' discourse about their work", International Journal of Project Management, Vol. 25 No. 6, pp. 552-9.

Whitty, S.J. and Schulz, M.F. (2007), "The impact of Puritan ideology on aspects of project management”, International Journal of Project Management, Vol. 25 No. 1, pp. 10-20.

Wideman, R.M. (1995), "Criteria for a project management body of knowledge", International Journal of Project Management, Vol. 13 No. 2, pp. 71-5.

Williams, T.M. (1999), “The need for new paradigm for complex projects”, International Journal of Project Management, Vol. 17 No. 5, pp. 269-73.

Williams, T.M. (2004), "Assessing and building on the underlying theory of project management in the light of badly over-run projects", paper presented at the PMI Research Conference, London.

Winch, G. (1996), "Thirty years of project management - what have we learned?", British Academy of Management Conference Proceedings, Aston Business School, Birmingham, pp. 8.127-45.

Zika-Viktorsson, A., Sundstrom, P. and Engwall, M. (2006), "Project overload: an exploratory study of work and management in multi-project settings", International Journal of Project Management, Vol. 24 No. 5, pp. 385-94.

\section{Further reading}

Baldry, D. (1998), "The evaluation of risk management in public sector capital projects", International Journal of Project Management, Vol. 16 No. 1, pp. 35-41.

Buchanan, D. and Badham, R. (1999), Power, Politics, and Organisational Change: Winning the Turf Game, Sage, London.

Engwall, M. and Jerbrant, A. (2003), "The resource allocation syndrome: the prime challenge of multi-project management", International Journal of Project Management, Vol. 21 No. 6, pp. 403-9.

Gill, R. (2002), "Cool, creative and egalitarian? Exploring gender in project-based new media work in Europe", Information, Communication and Society, Vol. 5 No. 1, pp. 70-89.

Lycett, M. and Rassau, A. et al., (2004), "Programme management: a critical review", International Journal of Project Management, Vol. 22 No. 4, pp. 289-99.

Miller, R. and Lessard, D.R. (2000), The Strategic Management of Large Engineering Projects, Massachusetts Institute of Technology Press, Boston, MA.

Morris, P.W.G. (1997), The Management of Projects, 2nd ed., Thomas Telford, London.

Morris, P.W.G. (2002), "Science, objective knowledge and the theory of project management", Proceedings of the Institute of Civil Engineering, Vol. 150, pp. 82-90.

Wood, M. (2002), "Mind the gap? A processual reconsideration of organisational knowledge", Organization, Vol. 9 No. 1, pp. 151-71.

\section{Corresponding author}

Damian Hodgson can be contacted at: damian.hodgson@mbs.ac.uk

To purchase reprints of this article please e-mail: reprints@emeraldinsight.com Or visit our web site for further details: www.emeraldinsight.com/reprints 